\title{
A Set of English Instructional Materials Using Task-Based Learning for News Production Management Study Program in STMM “MMMTC” Yogyakarta
}

\author{
Giovanna Gistha Wicita
}

\section{Abstract}

The News Production Management Study Program (NPMSP) in STMM "MMTC" Yogyakarta is a study program that has an English subject in the third semester. Due to the lack of time and materials for the students, English, which they will use a lot in journalism, becomes their barrier in learning. Therefore, this research attempted to develop a set of English instructional materials using task-based learning for the third semester students of the NPMSP STMM "MMTC" Yogyakarta. This research aimed to answer how the materials are developed and what the materials look like. To gather the information, the researcher adopted Borg \& Gall's (1986) Research and Development (R\&D) method which was combined with Kemp's instructional design model (1977) covering eight flexible steps. Due to time and financial constraints, only five steps of $R \& D$ were conducted in designing the materials. To gather the information, the researcher conducted some interviews. After designing the materials, the interview was conducted. The interview results showed that the designed materials were good, appropriate, and applicable. Nine suggestions were obtained to revise the materials which covered the level of difficulty of the text, the content of the exercises, the overview of the learning materials, teaching media, lesson plans, instructions, layout, and material implementation. The materials consist of six units. Each unit contains five sessions, namely "What's Up?", "Entering the Newsroom", "Journalists' Project", "Entering the News Editor Room", and "Lesson Learned".

Keywords: English materials, task-based learning, STMM “MMTC” Yogyakarta

\section{A. INTRODUCTION}

To maintain the expansion of mass media and produce some competent journalists, many institutions have established journalism courses. STMM "MMTC" is one of broadcasting colleges in Yogyakarta. STMM is the abbreviation for SekolahTinggi Multi Media and MMTC is the abbreviation for Multi Media Training Centre. One of its study programs, namely NPMSP, News Production Management Study Program, was the focus on this research. Based on the Academic Guidebook of STMM "MMTC" Yogyakarta (2010), there are nine competences. Two of them are having abilities to: (1) search, process, write, and deliver news using different kinds of format which are related to the characteristics of broadcasting media and (2) present the news using phrasing, intonation, articulation, reading speed, and pause mastery. In order to achieve those two competences, the college provides the opportunity for the third semester students to learn English through one of its concentration, namely Journalism English. However, students have limited time to learn English because of the condition of the curriculum. As mentioned earlier, there is 
only one English subject in the NPMSP STMM "MMTC" Yogyakarta, namely Journalism English. This subject is only given in the third semester in the new curriculum.

There are two reasons for the researcher to design a set of English instructional materials. The first reason is to provide a set of English instructional materials as there is no a set of English materials available. The set of English instructional materials is expected to help students to achieve the two academic goals stated previously. The second reason is to increase students' English ability in journalism. Furthermore, it can expand their experience in journalism through English.

Designing the materials for journalistic students was related to English for Specific Purposes (ESP). According to Hutchinson and Waters (1987), "ESP is an approach to language learning, which is based on learners' need, and an approach to language teaching in which all decisions as to content and method are based on the learner's reason for learning" (p. 19). The theory above is relevant to the condition of the third-semester students of the NPMSP STMM "MMTC" Yogyakarta whose major is journalism. Thus, the researcher designed the instructional materials based on their needs and interests as journalist candidates. The instructional materials would be related to journalism.

The approach to design a set of instructional materials for the third semester students of the NPMSP STMM "MMTC" Yogyakarta proposed by the researcher was Communicative Language Teaching (CLT). Since 1980s, the domination of CLT was significant. Larsen-Freeman (2000) states that "such observations contributed to a shift in the field in the late 1970s and early 1980s from a linguistic structure-centered approach to a communicative approach" (p.121). In other words, the application of the audio-lingual method was no longer popular. Therefore, the researcher proposed CLT as the approach of the designed materials. Furthermore, the researcher designed the materials using the communicative language as a need for the third semester students of the NPMSP STMM "MMTC" Yogyakarta because the NPMSP demands the students to be able to communicatively use English in journalism. The specific and general condition of the NPMSP is journalism. Since journalism is closely related to communication, therefore, CLT provides the opportunities for the students to communicate intently and meaningfully with others through English(Larsen-Freeman, 2000; Nunan, 2004; Wong and Raulerson, 1974).

Task-based learning, as one of the approaches in CLT, becomes a particular teaching approach proposed in the designed materials. Task-based learning is the approach to learn English by completing tasks as the classroom activities. As learners work to complete the tasks, task-based learning has abundant opportunities for the learners to interact with each other. Nunan (2004) states, "task-based language teaching is an approach to language teaching organized around tasks rather than language structures" (p.216). Based on the statement above, the researcher provided tasks in the designed materials to be classroom activities for the students to do. It is expected that the designed materials provided an effective teaching-learning process for the third semester students of the NPMSP STMM "MMTC" Yogyakarta.

Therefore, this study attempted to answer two research questions: (1) How is a set of English instructional materials using task-based learning for the third semester students of the News Production Management Study Program in STMM 
"MMTC" Yogyakarta developed? (2) What do the materials look like?

\section{B. DISCUSSIONS}

This research adopted Kemp's (1977) instructional model and Borg and Gall's (1983) Research and Development (R\&D) for developing the materials. The researcher combined five steps of $R \& D$ with Kemp's instructional design model. The five R\&D steps employed were research and information collecting, planning, developing preliminary form of product, preliminary field testing, and main product revision. The steps of the instructional design model taken were identifying students' characteristics, conducting pre-assessment, considering the goals, listing the topics, stating the general purposes, specifying the learning objectives, listing the subject contents, selecting the teaching-learning activities and resources, and considering the necessary support services.

In combining the five steps of $R \& D$ and Kemp's instructional design model, the researcher put the analysis of the data, such as conducting the need analysis, data analysis, guidelines for the designed materials, and data analysis to evaluate the materials. Firstly, research and information gatheringinvolves conducting needs analysis, data analysis, identifying students' characteristics, conducting pre-assessment, and guidelines for material design. Secondly, planning was divided into three parts, namely considering goals, listing topics, and stating general purposes, specifying the learning objectives, and listing the subject contents. Thirdly, developing preliminary forms of product contained selecting teachinglearning activities and resources and considering the necessary support service. Fourthly, preliminary field testing dealt with data analysis to evaluate the materials. Lastly, the main product revision was obtained in the end of designing the materials.

\section{Research and Information Collecting}

Research and information gathering involves conducting need analysis, data analysis, identifying students' characteristics, conducting pre-assessment, and guidelines for the material design. In conducting needs analysis, the English lecturer of the NPMSP STMM "MMTC" Yogyakarta and three journalists from three different media were interviewed in an in-depth way (Bogdan and Biklen, 2003; McCracken, 1998; Marshall and Rossman, 2006; Fontana and Prokos, 2007; Lichtman, 2013) by using interview protocol to make the interview well-arranged (Lodico et al, 2010; Patton, 2002; Lichtman, 2013, Cresswell, 2003). Furthermore, 68 questionnaires as suggested by Ary et al (2002) were distributed to 68 students who were divided into two classes.

In the data analysis, the researcher did coding categorization for the interview results (Bogdan and Biklen, 2003; Silverman, 1993, Lichtman, 2013, Miles \&Huberman, 1994; Patton, 2002; Merriam, 2009). There were four categories of learning method, learning materials, learning resources, and learning focus. Whereas after analyzing the questionnaires results by using Likert (1932) scale, it acquired some implications that: (1) the materials would employ task-based learning, (2) the materials would discuss journalism elements, (3) the materials would provide various learning resources, and (4) the focus of the materials would be the four English skills.

Furthermore, after students' characteristics were identified, some conclusions came up. They were: (1) the level of English language in the materials would be intermediate, (2) the researcher would provide various tasks, media, and or sources in order to make them more experience in learning English, (3) the researcher would facilitate the students to train more on four English skills through learning tasks, media, 
and or sources, (4) four English skills would be integrated, and (5) the researcher would facilitate the students by providing various media and classroom activities.

In the pre-assessment, the data included students' perception toward the difficulty in Journalism English and the existence of various English classroom activities in Journalism English. The results imply that the researcher would provide and international media, both printed and video since the media or the examples that were used in the teaching-learning process came from the local media, and also the researcher would provide more various activities in the designed materials.

The nextstep is combining the analysis of the interview result and descriptive survey to be the guidelines for the researcher to design the materials. The guidelines are: (1) the materials would be based on taskbased learning method, (2) four English skills would be the learning focus, (3) all English skills would be integrated, (4) the level of English was intermediate, (5) the researcher would provide sources taken from any international media, (6) the topics of the materials would focus on learning
English for journalism, (7) the materials would consist of various activities, and (8) there would be various tasks, media, sources, and activities. After arranging the guidelines, the researcher got the components of the materials. The components were gained from the results of the interview analysis, especially in the part of the learning English materials. However, based on the suggestion of the English lecturer of the NPMSP STMM "MMTC" Yogyakarta, the researcher revised the list of the components and the units of the materials by omitting some components and units by adding some other components that were suggested.

\section{Planning}

In planning, the researcher considered goals, listed topics, and stated general purposes, specified the learning objectives, and listed the subject contents. The components and units obtained from the previous step was developed. As the result of this step, the following table contains the presentation of the learning indicators for each topic.

Table 1. The Learning Indicators of the

\section{Designed Materials}

\section{General Purposes}

Topic 1: Introduction to News

1. The students know the basics of journalism.

2. The students know the definition of news.

3. The students know the news values.

4. The students know the types of news.
Learning Indicators

At the end of the lesson, the students are able

to:

1. Discuss the basics of journalism.

2. Recognize the definition of news.

3. Identify the news values correctly.

4. Discuss the types of news correctly.

5. Discuss simple past tense. 
Topic 2: News Structure

1. The students know how to make headline.

2. The students know how to make lead.

3. The students know the inverted pyramid.

Topic 3: Writing News

1. The students know how to recognize $5 \mathrm{~W}+1 \mathrm{H}$

2. The students know the types of sentences.

3. The students know how to analyze sentences.

4. The students know how to write news.

\section{Topic 4: Editing News}

1. The students know how to edit news.

2. The students know grammar mistakes in conjunction.

3. The students know how to rewrite news.

\section{Topic 5: Translating News}

1. The students know simple steps in translation.

2. The students know how to translate sentence from Indonesia to English.

3. The students know how to translate sentence from English to Indonesia.

Topic 6: Reading News

1. The students know how to pronounce correctly

2. The students know how to read news appropriately.
At the end of the lesson, the students are able

to:

1. Recognize headline in news.

2. Recognize lead in news.

3. Recognize inverted pyramid in news.

4. Practice how to make good headline and lead.

5. Discuss subject-verb agreement.

At the end of the lesson, the students are able

to:

1. Recognize $5 \mathrm{~W}+1 \mathrm{H}$.

2. Discuss types of sentences.

3. Discuss the sentences.

4. Write news correctly.

5. Discuss the use of punctuation.

At the end of the lesson, the students are able to:

1. Discuss grammar mistakes in conjunctions.

2. Discuss active-passive voice.

3. Rewrite news.

4. Discuss articles.

At the end of the lesson, the students are able to:

1. Recognize the steps of translating news.

2. Practice to translate sentence from Indonesia to English.

3. Practice to translate sentence from English to Indonesia.

4. Discuss prepositions (at, in, on)

At the end of the lesson, the students are able to:

1. Recognize English consonant and vowel sounds.

2. Pronounce words and sentences of news correctly.

3. Read news appropriately.

4. Discuss stress patterns.

\section{Developing the Preliminary Form of} Product

In developing the preliminary form of product, two Kemp's (1977) instructional design steps were adapted. Those two steps are selecting teaching-learning activities and resources and considering the necessary support services.Furthermore, the 
researcher used materials adaption to help the research to find the suitable materials for the students (Tomlison and Masuhara, 2004). In defining learning sessions for every meeting, the researcher adapted the concept of pre-task, task-cycle, and language focus in task-based learning framework. The researcher divided every unit of the materials into five sessions: What's Up?; Entering the Newsroom; Journalists' Project; Entering the News Editor Room; and Lesson Learned. The first session, "What's Up?" was designed to recall students' background knowledge on the topic. This phase would be related to students' daily activity which made them familiar with the new topic. "Entering the Newsroom", as the second session, provided some theories and exercises for the students to be ready in working on the main section of the designed material. "Journalists' Project" was the main session in every unit which consisted of some big projects for groups and pairs of the students to do. In becoming the language focus of every unit, "Entering the News Editor Room", provided grammar and the analysis. The last session was "Lesson Learned". The students would review the teaching-learning process in the form of answering questions or filling in the crosswords.

Task-based learning required the researcher to provide some exercises in every session in every unit. In doing the tasks, the teacher let the students to work individually, in pair, and in group in order to communicate the language, not only for themselves but also with other students. The presentations of various tasks in various activities in the designed materials can be seen in the following discussion.

\section{What's Up?}

The purpose of this session was to recall students' knowledge of the topic they are going to learn. The kinds of tasks used in this session were predicting, inducing, and co-operating that could be done individually and in pairs. To discuss the answer to this phase's questions, the students would be included in the classroom discussion in order to share their personal experiences on the topic.

\section{Entering the Newsroom}

Introducing some theories of the topic and the exercises aimed to prepare the students to deal with the main task. The activities that were appeared in this session were diagramming, using context, skimming and taking notes. Students had opportunities to do the exercises both individually and in pairs.

3. Journalists' Project

This session was the main phase of all. The students did not work alone since they had to synergize with bigger classroom activities in pairs and in groups. Students were engaged in pair work and group work in this session. The kinds of tasks applied were classifying, inducing, taking-notes, cooperating, role playing and using context.

4. Entering the News Editor Room

Entering the News Editor Room phase aimed to correct students' misunderstanding by providing new theories with the exercises as well. The news theories are related to the language focus of the topic. The tasks in this session covered diagramming, using context, taking notes and practicing. The level of task in this session was as important as the previous sessions; thus, the researcher also provided various tasks in this session.

\section{Lessons Learned}

This session provided the opportunities for the students to share what they have learned throughout the lesson. Lesson Learned prepared some questions in the form of the questions and crosswords. Hudelson (1993) suggests that "students can provide written or oral feedback on a course both during the course and after it has been taught, commenting on features 
such as the teacher's approach, the materials used, and their relevance to the students' need" (p. 299). In the designed materials, the researcher provided an evaluation in every units of the materials. It aimed to gain students' understanding toward the lesson through the tasks. Those tasks were inducing, co-operating, personalizing, self-evaluating, and reflecting. This session could be a way to monitor students' progress in understanding the materials.

In the teaching and learning process, there were four main facilities, as the support services. They were students' handbook, a white board, a set of speakers and VCD-MP3 players which would be useful for listening sections. In the classroom, there was also a supporting facility such as LCD projector. The researcher concluded that the necessary support services for implementing the taskbased learning were already available.

\section{Preliminary Field Testing}

Evaluating the materials, through conducting some interviews, demanded the researcher to evaluate whether the designed materials were appropriate for the students or not. The participants of the preliminary field testing were an English lecturer of the NPMSP STMM “MMTC” Yogyakarta, an English lecturer of the English Language Education Study Program of Sanata Dharma University, and a fresh graduate of the English Language Education Study Program of Sanata Dharma University. The analysis of the interview results in this step was the same as the analysis of the interview results in the research and information collecting. After listing coding categories, the researcher generated three themes, namely the appropriateness of the designed materials, detailed components as the strengths of the designed materials, and the level of difficulty of the English text as the weakness of the designed materials. The researcher concluded that some parts of the designed materials needed to be improved and revised. From the three interview results, the researcher listed nine suggestions that covered the text, content of exercise, overview of the materials, media, activity, instruction, layout, and material implementation. The detailed suggestions can be seen in the following table.

\section{Table 2. The Suggestions to Improve the Designed Materials}

\begin{tabular}{|c|c|c|}
\hline No. & Items & Suggestions \\
\hline 1. & Text & Reduce the level difficulty of the English news passages. \\
\hline 2. & Content of exercise (1) & $\begin{array}{l}\text { Add the optional vocabulary items or clues that can be } \\
\text { used to create sentences in order to minimize double } \\
\text { problems. }\end{array}$ \\
\hline 3. & Content of exercise (2) & Rearrange the list of terms into a good alphabetical order. \\
\hline 4. & Overview of the materials & $\begin{array}{l}\text { Add what the teachers should do in the overview of the } \\
\text { materials. }\end{array}$ \\
\hline 5. & Media & $\begin{array}{l}\text { Complete the activities in the lesson plan about asking } \\
\text { the students to browse the digital or online dictionary } \\
\text { instead of looking at the printed dictionary }\end{array}$ \\
\hline 6. & Activity & $\begin{array}{l}\text { Complete the activities in the lesson plan for the teacher } \\
\text { to explain the pictures cards first in order to avoid } \\
\text { students' misunderstanding. }\end{array}$ \\
\hline 7. & Instruction & Improve and revise some instructions. \\
\hline 8. & Layout & Rearrange the layout of the exercises. \\
\hline 9. & Material implementation & $\begin{array}{l}\text { Implement the material for a better material's } \\
\text { development. }\end{array}$ \\
\hline
\end{tabular}




\section{Main Product Revision}

The purpose of this step was to improve the designed materials to produce the final version. Improvements were made based on the evaluation comments and suggestions from the respondents of the preliminary field testing of the designed materials. Overall, the designed materials were already good and appropriate. However, nine points needed to be improved. The researcher used those nine points to consider improving the designed materials. After revising the materials based on the suggestions given by the respondents, the final version of a set of English instructional materials for the third semester students of the NPMSP in STMM "MMTC" Yogyakarta, both teacher's and student's book, was finally finished.

The set of English instructional materials consisted of two books: Teacher's Book and Student's Book. The Teacher's Book consisted of five parts: (1) the overview of the learning materials, (2) syllabus and lesson plans, (3) answer key to exercises, (4) transcript of the listening podcast, and (5) photocopiabletask materials.

The student's book consisted of six units. The arrangement of the six units was based on the research and information collecting from three journalists and the consultation with the English lecturer of the NPMSP in STMM "MMTC" Yogyakarta. The six units were (1) "Journalism and News", (2) "News Structure”, (3) "Let's Produce News!" (4) “Good News", (5) "News Translation”, and (6) "Reading News Appropriately!".

Every unit contained five sessions. The first session, "What's UP?" aimed to recall students' background knowledge toward the topic. Another purpose was to make the students familiar with the topic to learn. This session served as the pre-task phase in Willis' (1977) task-based learning framework. "Entering the Newsroom", as the second session of the unit, introduced the theory of related topic and also tasks to be done. This session served the pre-task phase in Willis' (1977) task-based learning framework. As the main session, "Journalists' Project" provided tasks to do in groups and pairs. The task had higher level of difficulty in this session and took longer time to finish it. This session served as the task cycle in Willis' (1977) task-based learning framework. The fourth session was "Entering the News Editor Room". This session provided grammatical aspects that were necessary for the students. This session focused on language. The last session in the unit was "Lesson Learner". This session gave the students an opportunity to evaluate the lesson through sharing and answering the questions in the form of essays and crosswords.

\section{CONCLUSIONS}

To answer the first research question, the researcher adapted the combination of R\&D cycle and Kemp's eight steps as the framework:

1. Research and Information Collecting. It consists of Kemp's steps, namely conducting need analysis, data analysis, identifying students' characteristics, conducting pre-assessment, and guidelines for the material design.

2. Planning. It was adapted from Kemp's steps, i.e. considering goals, list topics, and state general purposes, specifying the learning objectives, and listing the subject contents.

3. Developing Preliminary Form of Product. It includes Kemp's steps, i.e. conducting pre-assessment, selecting teachinglearning activities and resources, and considering the necessary support service.

4. Preliminary Field Testing. It is adapted from Kemp's step of evaluating the materials. 
5. Main Product Revision. It is adapted from Kemp's step of revising the materials.

To answer the second research question, the research conducted expert validation step by interviewing three respondents. The result of the interview indicated that the designed materials were already appropriate to be applied for the third semester students of the NPMSP STMM "MMTC" Yogyakarta. However, nine aspects of the designed materials that needed to be improved. The final version of the designed material was produced as the goal of this research. In adapting Willis' framework of the implementation of task-based learning, the researcher divided each meeting into five sessions, namely What's Up?, Entering the Newsroom, Journalists' Project, Entering the News Editor Room, and Lesson Learned.

\section{REFERENCES}

Ary, D., Jacobs, L. C., \&Razavieh, A. (2002). Introduction to research in education ( $6^{\text {th }}$ ed). Belmont: Wadasworth Thomson Learning.

Bari, H. (1995). Teknikdankomunik a sipenyiartelevisi-radio-MC: Sebuahpengetahuanpraktis. Jakarta: PT. GramediaPustakaUtama.

Berner, T. R. (1992). The process of writing news. Boston: Allyn \& Bacon.

Best, W. (1970). Research in education. London: Prentice Hall.

Bogdan, R. C., \&Biklen, S. K. (2003). Qualitative research for education: An introduction to theory and methods ( $4^{\text {th }}$ ed). Boston: Allyn \& Bacon.

Boone, H. N., \& Boone, D. A. (2012). Analyzing Likert Data. Journal of Extension. 50(2), 1-5.

Borg, W. R., \& Gall, M. D. (1983). Educational research: An introduction ( $\left.4^{\text {th }} \mathrm{ed}\right)$. New York: Longman Inc.

Borg, W. R., Gall, M. D., \& Gall, J. P. (2007). Educational research: An introduction
( $8^{\text {th }}$ ed). New York: Longman Inc.

Brown, J. D., \& Rodgers, T. S. (2002). Doing second language research. Oxford: Oxford University Press.

Cresswell, J. W. (2003). Research design: Qualitative, quantitative, and mixed methods approaches $\left(2^{\text {nd }} e d\right)$. London: Sage Publications Ltd.

Dudley-Evans, T. (1998). Developments in English for specific purposes. New York: Cambridge University Press.

Dudley-Evans, T., \& St. John, M. (1998). Developments in ESP: A multidisciplinary approach. Cambridge: Cambridge University Press.

Fraenkel, J. R., \&Wallen, N. E. (1993). How to design and evaluate research in education. New York: McGraw Hill.

Gagne, R. M., \& Briggs, L. J. (1979). Principles of instructional design. New York: Holt, Rinehart, and Winston.

Graves, K. (2000). Designing language courses: A guide for teachers. Boston: Thomson Heinle.

Hudelson, S. (1993). English as a second language curriculum resource handbook. New York: Krause International.

Hutchinson, T., \& Waters, A. (1987). Specific purposes. Cambridge: Cambridge University Press.

Ishwara, L. (2005). Catatancatatanjurnalismedasar. Jakarta: PenerbitBukuKompas.

Jeremy, D., \&Krzanowski, M. (2011). Teaching English for specific purposes: An introduction. Cambridge: Cambridge University Press.

Johnson, K., \& Porter, D. (1983). Perspectives in communicative language teaching. Boston: Academic Press, Inc.

Joyce, Bruce, \& Weil, M. (1986). Models of teaching. New York: Prentice Hall, Inc. 
Keir, D. (1957). Newspaper. Camden Town: Edward Arnold Ltd.

Kemp, J. E. (1977). Instructional design (plan for unit and course development) $\left(2^{\text {nd }} e d\right)$. Belmont, CA: Fearon-Pitman.

Larsen-Freeman, D. (2000). Techniques and principles in language teaching. Oxford: Oxford University Press.

Likert, R. (1932). A technique for the measurement of attitudes. Archives of Psychology, 22(140), 1-55.

Littlework, W. (1977). Communicative language teaching: An introduction. New York: Cambridge University.

Lodico, M. G., Spaulding, D. T., \&Voegtle, K. H. (2010). Methods in educational research: From theory to practice $\left(2^{\text {nd }} e d\right)$. Hoboken: John Wiley \& Sons, Inc.

Marshall, C., \&Rossman, G. B. (2006). Designing qualitative research $\left(4^{\text {th }}\right.$ ed). Thousand Oaks, CA: Sage Publications, Inc.

McCracken, G. (1998). The long interview. Newbury Park, CA: Sage.

Merriam, S. B. (2009). Qualitative research: A guide to design and impelementation. San Fransisco, CA: John Wiley \& Sons, Inc.

Metlzer, K. (1986). Newsgathering. Englewood Cliffs, NJ: Prentice Hall, Inc.

Meltzer, K. (2010). TV news anchors and journalistic tradition: How journalists adapt to technology. New York: Peter Lang Publishing.

Miles, M. B., \&Huberman, A. M. (1994). Qualitative data analysis: An expanded sourcebook ( $\left.2^{\text {nd }} e d\right)$. Thousand Oaks, CA: Sage.

Morgan, D. L. (1998). The focus group guidebook. Thousand Oaks, CA: Sage Publications, Inc.
Nunan, D. (2003). Practical English language teaching. New York: McGraw Hill Companies.

Nunan, D. (2004). Task-based language teaching. Cambridge: Cambridge University Press.

Olii, H., M. M., \&Hozilah, L. (2013). Reportase radio \&televisi: Bahan ajar di perguruantinggi(Edisi ke-2). Jakarta: PT. Indeks.

Patton, M. Q. (2002). Qualitative research and evaluation methods ( $\left.3^{\text {rd }} \mathrm{ed}\right)$. London: Sage Publications Ltd.

Reah, D. (2002). The language of newspaper $\left(2^{\text {nd }} e d\right)$. New York: Routledge.

Reddick, D. C. (1941). Journalism and the school paper. New York: D. C. Health and Company.

Richards, J.C.(2001). Curriculum development in language teaching. New York, NY: Cambridge University Press.

Richards, J. C. (2002). Planning aims and objectives in language programs. Singapore: SEAMEO Regional Language Centre.

Richards, J. C. (2005). Communicative language teaching today. Singapore: SEAMEO Regional Language Centre.

Richards, J. C., \& Rodgers, T. S. (2001). Approaches and methods in language teaching $\quad\left(2^{\text {nd }} e d\right)$ Cambridge: Cambridge University Press.

Rivers, W. M. (1983). Communicating naturally in a second language: Theory and practice in language teaching. Cambridge: Cambridge University Press.

Romli, A. S. M. (2005). Jurnalistikpraktisuntukpemula. Bandung: PT RemajaRosdakarya.

Seliger, H. W., \&Shohamy, E. (1989). Second language research methods. Oxford: Oxford University Press. 
Silverman, D. (1993). Interpreting qualitative data: Methods for analyzing task, text, and interaction. Thousand Oaks, CA: SAGE Publications Inc.

Skehan, P. (1996). A framework for the implementation of task-based instruction. Oxford: Oxford University Press.

Stake, R. E. (1994). Handbook of Qualitative Research. Thousand Oaks: Sage Publications.

Strauss, A., \& Corbin, J. (1998). Basics of qualitative research: Techniques and procedures for developing grounded theory. City Road, London: SAGE Publications Ltd.
Tomlinson, B., \&Masuhara, H. (2004). Developing language course material. Singapore: SEAMEO Regional Language Centre.

Webster's Encyclopedic Unabridged Dictionary of the English Language. (1996). San Diego, CA: Thunder Bay Press.

Widdowson, H. C. (1987). Aspects of syllabus design. Singapore: RELC.

Willis, J. (1996). A framework for task-based learning. London: Pearson Education.

Wong, M. R., \&Raulerson, J. D. (1974). A guide to systematic instructional design. Englewood Cliffs, NJ: Educational Technology Publications, Inc.

Yunus, S. (2010). Jurnalistikterapan. Bogor: PenerbitGhalia Indonesia. 